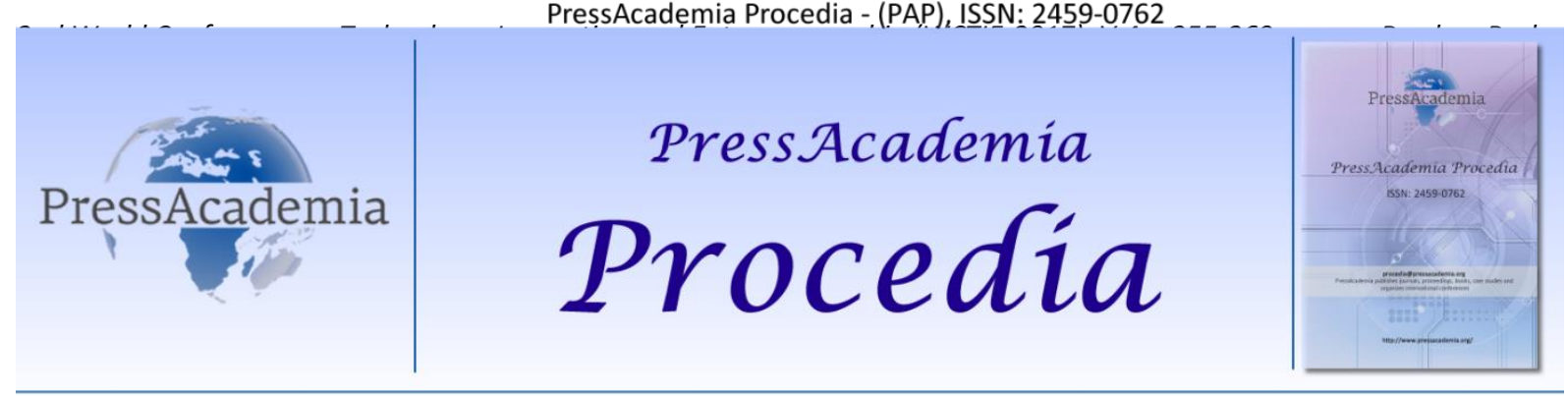

2nd World Conference on Technology, Innovation and Entrepreneurship

May 12-14, 2017, Istanbul, Turkey. Edited by Sefer Şener

\title{
BEGINNING OF THE END CAPITALISM: MACRO EFFECTS OF THE 2008 FINANCIAL CRISIS -THE CASE OF TURKEY
}

\section{DOI: 10.17261/Pressacademia.2017.541 \\ PAP-WCTIE-V.4-2017(33)-p.255-260}

Gumrah Can Basdag ${ }^{1}$ Emin Barlas ${ }^{2}$

${ }^{1}$ Kilis 7 December University, gumrahbasdag@kilis.edu.tr

2 Gaziosmanpasa University, emin.barlas@gop.edu.tr

\begin{abstract}
Economic turmoil of worldwide began to Express discourse since 2007. Hazard has shown itself that repayment of subprime mortgage loans, fall in property prices and it give the signal of financial institutions. A large increase in all commodities and agricultural products took place in the early 2000s. Food prices reached their highest level in 2008. US dollar fell considerably against other currencies. Immovable property market(residential) occured because of a large fall in paralel with the decline of the US dollar. US residential prices tended to rise since the early 2000s. The reason being the trend of mortgage loans. Mortgage loans in the market that it has created excessive optimism, and it created an environmet that allows even low-income people to easily find loans to buy housing. Residential subprime mortgage market collapsed with the passing down of prices and the borrower has led to the bankruptcy of low-income families.
\end{abstract}

Keywords: Crisis, subprime, mortgage, low-income

JEL Codes: G01; G10

\section{INTRODUCTION}

Since the beginning of the 19th century, which is the period when everything has started to be measure with money, also known as capitalism, various crises have occurred(Bozan, 2015). The crises that took place in the 1800s were mostly financial, speculative and because of war, and the crises that took place after 1900s were mostly from financial reasons (Yücel and Kalyoncu, 2010, p: 53). The economic crises with a potential to affect the economy of a country at its fullest can be addressed formally at two different points. Firstly, crises named as real sector crises appear differently according to the goods and services market and the labor market. It emerges as a crisis of inflation and recession in the goods and services market, and as a crisis of unemployment in the labor market. Secondly, the emerging economic crises manifest themselves in the form of a financial crisis. The main reason for financial crises is the crises that occur in the monetary markets (Yücel and Kalyoncu, 2010, p: 54). When the macroeconomic effects of the crises emerging in the financial markets are examined, especially in banking, significant output is generated (Ural, 2003, p: 15). Financial crises, which are the major indicators of the uncertainty in banking, find much place in today's global economy and become increasingly important.

The global crisis, which began in the US in September 2008 and immediately affected all economies, underlining the credit and real estate bubble; (Afşar, 2011, p: 148), because the crises emerged in the financial markets were the last and spread around the world. In this study; the perception of financial crisis and its types are considered as basic, the origin of the 2008 global crisis, its global effects, and whether there is an economic vulnerability in expressing this crisis as "tangential" in Turkey has been investigated.

\section{CONCEPT OF FINANCIAL CRISES}

The concept of crisis came from the Greek word "krisis" as etymological origin, and means "depression" in social sciences (Turgut, 2006, p: 35). The phenomenon named as financial crisis can be called as the negative effect of financial institutions 
on the financial markets (Işık, Duman and Korkmaz, 2004, p: 46). Mishkin ${ }^{1}$ describes the financial crisis as follows: "Financial crisis, adverse selection and moral hazard problems are a deterioration in the financial markets. This deterioration in the financial markets has inactivated the transfer of mutual funds to the most productive investment opportunities ". Under these conditions, when the economic cycles are considered, inefficient investment expenditures mean inefficient production, naturally causing the size of the crisis to multiply exponentially.

Financial crises can have devastating effects on financial institutions. In this context, firstly, the originating point of financial crises should be determined. According to Mishkin, financial crises arise from the following four items:

1- Balance sheet breakdown of financial institutions

2- Increase in interest rates

3- Uncertainty

4- The deterioration of the balance of non-financial institutions (Delice, 2003, p: 58).

According to other authors, the financial crises that affect the system in general are largely due to general macroeconomic imbalances from individual financial institutions.

\subsection{Types of Financial Crisis}

Financial crises are divided into four subdivisions that can not be distinguished from each other: Monetary Crises, Banking Crises, External Debt Crises and Systemic Crises (Sachs, 1998, p: 243).

\subsubsection{Monetary Crises}

Monetary crises are also called currency crises. Especially, in the systems where fixed exchange rate is adopted, crises arise as a result of foreign exchange fluctuations from the national currency due to a sudden change in the demands of the participants in the market and the depletion of the foreign exchange reserves under the possession of the Central Bank (Turgut, 2007, p.36). The theoretical infrastructure of money crises has been tried to be established with two models which have a continuity with one another. Krugman (1979) and Flood and Garber (1984) form first-generation models of money crises, while Obstfeld (1986) reveals second-generation models. According to Krugman (1979) model, while the fixed exchange rate is valid, the increase of the national credit volume over the money demand causes the constant decrease of the country reserves and generation of a speculative perception regarding the currency of the country (Karabacak, 2010, p: 253). According to the study of Obstfeld (1986), which expresses the second generation models, continuing with the fixed exchange rate contrary to the Krugman model implies that the necessity of implementing a more liberal monetary policy is the end result of the dilemma (Karabacak, 2010, p: 253).

\subsubsection{Banking Crises}

These are the crises that arise as a consequence of the liquidity problems of commercial banks. They occur as a result of the instantaneous demand increase from transactional accounts or as a result of the extension of the debt budget (Arslan and Çütcü, 2012, p: 217). The banking crisis tends to last longer than the currency crises and has a more severe impact on the economy (Delice, 2003, p: 61). As a result of speculative attacks due to the constant exchange rate in pre-crisis period, the international reserve is significantly reduced, and the increase that will eventually take place in the non-returning lending results in banking crises (Turgut, 2007, p: 37). From the 1970s to the 2000s, monetary and banking crises coexisted. Such crises are called "Twin Crises" (Kaminsky and Reinhart, 1999, p: 475).

\subsubsection{Foreign Debt Crises}

It is an inability to pay the public or private sector foreign debt of a country. This crisis arises when the external borrower fails to fulfill its obligations and be bound by the new payment plan (Delice, 2003, p: 61). Each country has its own credit notes when it is considered as public and private sector. Individuals or institutions with a tendency to give out debt make assessments in accordance with these credit notes and generate lending motivation in a suitable way. Persons or institutions that are motivated to lend try to give up new loans and try to withdraw existing loans when they think that the debtor can not pay their debts. If risk perception is high, a decrease in private capital inflows will occur (IMF, 2002, p: 6). While there is a situation where the money crisis and banking crises can affect the whole world financial system, the external debt crisis is limited only between the debtor and the creditor (Turgut, 2007, p: 38). The debtor and creditor will take the status of determining position depending on whether the foreign debt crisis is temporary or not. In any case, the debtor will want to solve the liquidity problem and close the debt, while the creditor will need to review the lending status in accordance with the dynamics of economy (Turgut, 2007, p: 38).

\footnotetext{
${ }^{1}$ Frederic Mishkin is an American economist and academics at the Columbia University, School of Business.
} 


\subsubsection{Systemic Crises}

Systemic crisis is the concept used fir the shocks that cause a negative perception on real economy which interrupt the important functions of financial system such as credit, payments and asset assessment (Yucel and Kalyoncu, 2010, p: 56). In times of political change, the economic policies implemented in the country can not demonstrate the desired effect, and it can cause serious breakowns in financial markets. Since these breakdowns in the markets will cause changes in the economy, newly implemented economic policies in the country will not be able to provide the desired effect. During periods of systemic crisis, losses in production come to the foreground, national income falls, economic losses increase, and the country faces serous economic problem (Turgut, 2007, p: 39).

\section{2008 GLOBAL CRISIS}

With the contribution of technological improvements, there has been a remarkable development in the financial markets over the last 20 years. The phenomenon of globalization has evolved into a structure becoming stronger after years of transformation in the 1980s and gained a structure without any geographical borders in terms of finance. The system has also abolished the concept of time and the markets have been functioning for 24 hours. The origin of the global crisis, which began in the United States before September 2008 and then spread to other parts of the world, is the largest real estate and credit bubble in history (Afşar, 2011, p: 148). As a result of the excessive politicization of rating agencies, the failure of regulatory and supervisory agencies to be insufficiently audited, lack of transparency and excessive securitization can be indicated as the reasons of crisis (Alantar, 2008, p: 2).

\subsection{Mortgage System}

The so-called mortgage system operates on both primary and secondary markets: Primary markets are the markets where buyers and sellers are directly involved, without any intermediary (Berberoğlu, 2009, p: 120). Secondary markets are the markets that provide funding from the capital markets to the primary markets. They have the role of intermediary market (Berberoğlu, 2009, p: 120). Mortgage loans are mainly provided by financial institutions as long-term loans to those who want to own a house, and mortgages are put as collateral. The mortgage remains until the debt is paid, but when the debt is fully paid and the debtor becomes the owner, then the collateral is abolished.

In the operation of the mortgage system, the following order is pursued:

1-The person who wants to own the property finds the real estate.

2- Negotiations begin with seller after finding the property.

3- The person who wants to purchase the property will go to the most suitable bank and request credit.

4- Bank implements the necessary research.

5- If the result of research is appropriate, then the credit is provided (Bayhan, 2015)

In the mortgage system, if the debtor cannot or will not pay its debt in the period it has undertaken, then it can sell the real estate for which it has made collateral and collect its receivables. The mortgage market in the US had a volume of about $\$$ 12 trillion, making the US mortgage market the world's largest. The major cause of this vast market size is the high risk mortgage loans provided in 2008 and before (Afşar, 2011, p: 148). In 2008, when these loans have reached to a level of no refund, the system was self-locked and faced with the greatest crisis of its history. This crisis had very severe global results.

\subsection{Impacts of Global Crisis}

2008 Global crisis is different from 1929 depression and other crises and it is the first global based crisis. In 1929 depression, which is considered as the greatest crisis before 2008 Global Crisis did not effect the reserved socialist countries (Eğilmez, 2013). The global crisis, beginning with the mortgage crisis in 2006 and reaching to a peak point with the 2008 Lehman Brothers crisis, is a macro result for both the developed and developing countries of the world.

Table 1: Impact of Global Crisis on Growth (World Line - \%)

\begin{tabular}{|l|c|c|c|c|c|c|c|}
\hline WORLD & $\mathbf{2 0 0 6}$ & $\mathbf{2 0 0 7}$ & $\mathbf{2 0 0 8}$ & $\mathbf{2 0 0 9}$ & $\mathbf{2 0 1 0}$ & $\mathbf{2 0 1 1}$ & $\mathbf{2 0 1 2}$ \\
\hline Growth & 4.0 & 4.0 & 1.5 & -2.2 & 4.1 & 2.9 & 2.5 \\
\hline
\end{tabular}

Source : IMF

As seen in Table 2, in the year 2006, when the crisis started, and in 2007, there was no decrease in the economic growth rates in the world and in 2008, when Lehman Brothers crisis occurred, it has tended to decrease again and the world has economically declined in 2009. The impact of crisis was felt around the world in 2009. Growth was restored in 2010, but in 
the following years the economy grew at a slower pace. As a result of this, the world needs to generate new ways to grow economically and that the old systems are not adequate for growth.

Table 2: Impact of Global Crisis on Inflation (World Line - \%)

\begin{tabular}{|l|c|c|c|c|c|c|c|}
\hline WORLD & $\mathbf{2 0 0 6}$ & $\mathbf{2 0 0 7}$ & $\mathbf{2 0 0 8}$ & $\mathbf{2 0 0 9}$ & $\mathbf{2 0 1 0}$ & $\mathbf{2 0 1 1}$ & $\mathbf{2 0 1 2}$ \\
\hline Inflation & 3.7 & 4.1 & 6.0 & 2.4 & 3.7 & 4.9 & 3.9 \\
\hline
\end{tabular}

Source : IMF

As seen in Table 3, while the global crisis peaked in 2008, when the peak of the crisis began, there was a decrease of about $3.6 \%$ in the inflation in 2009, the year when the impact of crisis was witnessed. The reason of this is the major decrease in demand (Eğilmez, 2013). Inflation, which has been on the increase since 2010, when the impact of the crisis has started to ease, tended to decline by $1 \%$ in 2012 compared to 2011, due to the contraction in economic growth.

Table 3: Impact of Global Crisis on Trade Increase (World Line - \%)

\begin{tabular}{|l|c|c|c|c|c|c|c|}
\hline WORLD & $\mathbf{2 0 0 6}$ & $\mathbf{2 0 0 7}$ & $\mathbf{2 0 0 8}$ & $\mathbf{2 0 0 9}$ & $\mathbf{2 0 1 0}$ & $\mathbf{2 0 1 1}$ & $\mathbf{2 0 1 2}$ \\
\hline Trade Increase & 9.2 & 8.0 & 3.1 & -10.6 & 12.5 & 6.0 & 2.5 \\
\hline
\end{tabular}

Source : IMF

As seen in Table 3, in 2006, when the crisis began, in the crisis, the peak of the trade declined until 2008, and in 2009, it contracted. As a result of this contraction, it can be shown that the decrease in trade is due to the lack of production and the decrease of trade. One of the reasons of this contraction is the businesses shut down as a result of 2008 global crisis. In 2008, approximately 250 businesses were closed for bankruptcy in the geographical region formed by EU, USA and Japan. (POSTA, 2009).

Table 4: Impact of Global Crisis on Unemployment (World Line - \%)

\begin{tabular}{|l|c|c|c|c|c|c|c|}
\hline WORLD & $\mathbf{2 0 0 7}$ & $\mathbf{2 0 0 8}$ & $\mathbf{2 0 0 9}$ & $\mathbf{2 0 1 0}$ & $\mathbf{2 0 1 1}$ & $\mathbf{2 0 1 2}$ & $\mathbf{2 0 1 3}$ \\
\hline Unemployment & 5.5 & 5.6 & 6.2 & 6.1 & 6 & 6 & 6 \\
\hline
\end{tabular}

Source: ILO

As shown in Table 4, the effect of the crisis in 2006 has caused $5.5 \%$ unemployment in 2007 and a similar unemployment figure appeared in 2008 when the crisis has increased impact. However, the impact of the global crisis in 2008 has affected all over the world in 2009, and as a result, unemployment increased by half a percentage point in 2009 . When we think of this rate as the world population, the end result is that the millions of people are left unemployed. In 2010 and following years, when the impact of crisis has started to decrease, the unemployment has declined, however, the period before the crisis could not be reached. We can say that the increase of population and no new businesses to replace the ones that have been shut down is the main reason for this.

\section{REFLECTIONS OF 2008 GLOBAL CRISIS ON TURKEY}

Although Turkey is a country that experienced many crises in the 1980s and before that, post-1980 crises are the ones that had huge impacts. The major crises that Turkey has experienced since 1980 are known as crises of 1994, 1998 and 2001 (Karabicak, 2010, p: 255). As these crises mostly affect the people who demand funds and the people and institutions that provide funds, the crises of 1994 and 2001 are called financial sector crises. However, the 2008 global crisis can be defined as the real sector crisis because it affects the sectors outside the financial sector that produce directly the goods (Yücel and Kalyoncu, 2010, p: 60). The global crisis has started in US in 2008 and spread all around the world, and it was felt in Turkey, which was passing over the 2001 crisis and caused various macro economical impacts and results.

Table 5: Growth Rates in Turkey by Years (\%)

\begin{tabular}{|l|l|l|l|l|l|l|l|}
\hline TURKEY & $\mathbf{2 0 0 6}$ & $\mathbf{2 0 0 7}$ & $\mathbf{2 0 0 8}$ & $\mathbf{2 0 0 9}$ & $\mathbf{2 0 1 0}$ & $\mathbf{2 0 1 1}$ & $\mathbf{2 0 1 2}$ \\
\hline Growth & 6.9 & 4.7 & 0.7 & -4.8 & 9.2 & 8.8 & 2.1 \\
\hline
\end{tabular}

Source : IMF

As seen in Table 5 there is a noticeable decline in the economic growth rates since 2006, when the crisis began in Turkey. The Turkish economy, which grew only $0.7 \%$ in 2008 with the impact of the global crisis, which began to be felt more and more since November 2008, and it had a contraction rate of $4.8 \%$ in 2009 due to decrease in production and trade. However, in 2010, following the active role of government in market and due to various incentives, the Turkish economy has seen a historical growth rate of $9.2 \%$. However, in the years following 2010 , there has been an evolution towards the $5 \%$ growth rate that the country has targeted. 
Table 6: Inflation Rates in Turkey by Years (\%)

\begin{tabular}{|l|l|l|l|l|l|l|l|}
\hline TURKEY & 2006 & 2007 & 2008 & 2009 & 2010 & 2011 \\
\hline Inflation & 9.6 & 8.3 & 10 & 6.5 & 6.4 & 10.4 & 6.1 \\
\hline
\end{tabular}

Source: TUIK

As seen in Table 6, in the period from 2006, when the crisis started in Turkey, to 2007, there was an approximate $1.3 \%$ of decrease in inflation. For this reason, it can be shown that there is a decrease in demand. In 2008, when the global crisis was at its peak, the inflation has increased and the growth rates have declined dramatically. In addition, when we look at the unemployment rates, we see $11 \%$ increase (PARA \& BORSA, 2014). This is a state of "stagflation". In other words, inflation and recession occurred together. Both high prices and high level of unemployment have been encountered. As of 2009, there was a downward trend in inflation, in line with the low growth rate and low demand level.

Table 7: Export Figures in Turkey by Years (billion \$)

\begin{tabular}{|l|l|l|l|l|l|l|l|}
\hline TURKEY & $\mathbf{2 0 0 5}$ & $\mathbf{2 0 0 6}$ & $\mathbf{2 0 0 7}$ & $\mathbf{2 0 0 8}$ & $\mathbf{2 0 0 9}$ & $\mathbf{2 0 1 0}$ & $\mathbf{2 0 1 1}$ \\
\hline Export & 73.4 & 85.5 & 107.2 & 132 & 102.1 & 113.8 & 134.9 \\
\hline
\end{tabular}

Source: TIM

As can be seen in Table 7, while exports continued to show a steady upward trend until the peak year of the crisis in 2008, the crisis tended to decline from November 2008, and it declined by 30 billion $\$$ in 2009, becoming 102 billion $\$$. This decline occurred all around the world, the lack of production, the shrinking of trade and the drop in the demand have been effective. However, in the following years, both public policies and incentives have led to an upward trend in exports.

Table 8: Unemployment Rates in Turkey by Years (\%)

\begin{tabular}{|l|l|l|l|l|l|l|l|}
\hline TURKEY & $\mathbf{2 0 0 6}$ & $\mathbf{2 0 0 7}$ & $\mathbf{2 0 0 8}$ & $\mathbf{2 0 0 9}$ & $\mathbf{2 0 1 0}$ & $\mathbf{2 0 1 1}$ & $\mathbf{2 0 1 2}$ \\
\hline Unemployment & 10.2 & 10.3 & 11 & 14 & 11.9 & 9.8 & 9.2 \\
\hline
\end{tabular}

Source: TUIK

As seen in Table 8, in the year 2006 when the crisis began, the rate of unemployment, the closing enterprises, the decrease in production, etc., which had a steady upward trend until the peak of the crisis in 2008, reached a rate of $14 \%$ in 2009 and the single-digit unemployment figures. However, the measures taken have tended to decline since 2010 due to factors such as incentives for the establishment of new businesses, and a positive shift in public policies towards employment.

\section{CONCLUSION}

The world was shaken by the global financial crisis, which began in 2006 and reached to its peak in 2008, that began in the US and then affected all financial markets. Although various measures have been taken, the global crisis has been felt strongly in all countries, and 2009 and 2010 have been lost years for many markets. These losses are seen in growth rates, trade volumes, changes in inflation rates, and unemployment figures when we look at the world as a whole. When we look at the underlying causes of the global financial crisis, it seems that the credit and real estate bubbles are the main reasons behind. The idea that the mortgage system could offer the people with low-budgets an opportunity to have a house was attractive at first and the system entries were realized without thinking the result. However, when the credits received in the system could not be recovered, the business has ended in a complete failure in terms of buyers and intermediaries. Those people who wished to own house have also lost their immovables that they have accumulated in their hands as well as mortgages. As the intermediaries could not be refunded, they have witnessed processes ending wit bankruptcy. In terms of Turkey, the banking system forms the basis of the financial market (Afşar, 2011, p: 169). Because majority of financial sources in Turkey are collected by the banks. In many countries, especially in the USA, the banks have suffered billions of dollars in losses and faced bankruptcy, the Turkish banking system has not been affected by the 2008 global crisis. In the 2001 financial sector crisis, 18 banks in Turkey were bankrupt; however no banks were bankrupt in 2008 global crisis. The reason of this is the banking system with a solid infrastructure without any shortage of foreign currency. Although the Turkish banking system was "tangential" to the crisis, macroeconomic data in Turkey has suffered losses in parallel with world markets in the years 2009 and 2010, the peak year 2008 and the following two years, but the impact was not as negative as it was in US and other countries affected. However, claiming that Turkey was not affected from the crisis at all does not reflect the truth. 


\section{REFERENCES}

Afşar, M. 2011, "The Global Crisis and Reflections at Turkish Banking Sector", Eskisehir Osmangazi University Faculty of Economics and Administrative Sciences Journal, vol:6, no:2, pp. 143-171

Alantar, D. 2008, "The Global Financial Crisis: An Assessment of the Causes and Consequences", Finance and Finance Articles, Retrieved at April 02,2017, from http://finanskulup.org.tr/maliyefinans/html.

Arslan, i.., Çütcü, ì. 2012, "Reflections and Suggestions of Financial Crisis", $4{ }^{\text {th }}$ International Congress on Entrepreneurship, Manisa, pp.216-224

Bayhan, A. 2015, "What is Mortgage? Information about the types and Functioning", Retrieved at April 02,2017, from http://paratic.com/mortgagekredisi-nedir-turleri-nelerdir/

Berberoğlu, M.2009, “Mortgage System and its Applicability in Turkey”, International Journal of Economic and Administrative Studies, vol:1, no:2, pp. 119-146

Bozan, E. 2015, "Capitalism and Capitalism 5 Basic Policy", Retrieved at April 02,2017, from http://ekonomist.co/akademi/kapitalizm-vekapitalizmin-5-temel-ilkesi-6854/

Delice, G. 2003, "Financial Crises: Theoretical and Historical Perspective", Erciyes University Faculty of Economics and Administrative Sciences Journal, pp. 57-81

Eğilmez, M. 2013, "Where are we in the Global Crisis?", Retrieved at April 01,2017, from http://mahfiegilmez.com/2013/04/kuresel-krizinneresindeyiz.html

IMF, 2012, "Eye of the Storm: New-Style Crises Prompt Rethink About Prevention and Resolution Measures", Finance \& Development, pp. 4-7

Kaminsky, G., Reinhart, C.M. 1999, "The Twin Crises: The Causes of Banking and Balance of Payments Problems", American Economic Review, vol:89, no:3, pp.475-500

Karabıçak, M. 2010, "The Reasons of Global Crisis and Turkish Dimension of the Global Crises", Suleyman Demirel University Faculty of Economics and Administrative Sciences Journal, vol:15, no:3, pp. 251-270

POSTA, 2009, “How many Sank company in crisis?”, Retrieved at March 26,2017, from http://posta.com.tr/krizde-kac-sirket-batti-mrauf-ates-yazisi$\underline{357}$

Sachs, J. 1998, “Alternative Approaches to Financial Crises in Emerging Markets”, Capital Flows and Financial Crises(Ed.), pp.243-262

Turgut, A. 2007, "Types, Causes and Indicators of Financial Crisis", TUHIS Journal of Business Law and Economics, vol:20, no:4, pp. 35-46

Ural, M. 2003, "Financial Crisis and Turkey", Dokuz Eylul University Faculty of Economics and Administrative Sciences Journal, vol:18, no:1, pp. 11-28

Yucel, F., Kalyoncu, H. 2011, "Leading Economic Indicators and the Breakthrough Channels of Financial Crisis: The Case of Turkey", Finance Journal, pp.54-59. 